\title{
SISTEM INFORMASI GEOGRAFIS DETEKSI LOKASI KEBAKARAN LAHAN JATI DI DESA KALIJAMBE KECAMATAN BRINGIN KABUPATEN SEMARANG
}

\author{
Avin Wimar Budyastomo \\ Dosen Komunikasi dan Penyiaran Islam IAIN Salatiga \\ bwimar@gmail.com
}

\begin{abstract}
Kalijambe village is a village located in Bringin sub district of Semarang. The geographical position of the village Kalijambe is still largely in the form of rubber and teak plantations. Thus, the dry season is very prone of fires. The cause of the fire itself is caused by the citizens who burned the bush and grass growing around the rubber plants and teak. In the other hand, this case was not recognized by people that it was the cause of the fire. Geographic Information System to detect the fire location is intended to help Kalijambe village government to see the areas affected by fire through the coordinate points contained on google map fire. The method used was the method of field survey conducted periodically. This research resulted that the affected areas were known and signed with black mark on the map location.
\end{abstract}

Keywords: SIG, Google MAP API, Kalijambe Village

\begin{abstract}
Abstrak
Desa Kalijambe adalah salah satu desa yang terletak di Kecamatan Bringin Kabupaten Semarang. Letak geografis dari desa Kalijambe sebagian besar masih berupa lahan perkebunan Karet dan Jati. Sehingga pada musim kemarau sangat rawan terhadap kebakaran. Penyebab dari kebakaran itu sendiri dari warga yang membakar lahan untuk membersihkan rumput maupun tumbuhantumbuhan kecil yang berada disekitar tanaman karet dan jati. Namun hal tersebut belum disadari oleh warga akibat dari pembakaran tersebut. Sistem Informasi Geografis Deteksi lokasi kebakaran ini bertujuan untuk membantu pemerintah desa kalijambe melihat daerah terdampak kebakaran melalui titiktitik koordinat yang terdapat pada google map api. Metode penelitian yang digunakan adalah metode survey lapangan yang dilakukan secara periodik. Hasil yang dicapai dalam penelitian ini adalah mengetahui letak daerah yang terdampak oleh kebakaran yang ditandai dengan warna hitam pada peta lokasi.
\end{abstract}

Kata Kunci: SIG, Google MAP API, Desa Kalijambe 


\section{Pendahuluan}

Desa Kalijambe adalah salah satu desa yang terletak di Kecamatan Bringin Kabupaten Semarang. Letak geografis dari desa Kalijambe masih berupa lahan tanaman Jati dan tanaman Karet. Sebagian besar penduduknya bermata pencaharian sebagai petani. Tanaman Jati dan Karet yang ditanam sebagian milik warga dan sebagian milik PTPN IX Kebun Getas Jawa Tengah. Pada musim kemarau ada beberapa warga yang membakar lahan tanaman Jati untuk membersihkan rumput ataupun sisa daun Jati yang gugur guna menambah kesuburan tanaman Jati. Namun dampak dari kebakaran ini sangatlah banyak, diantaranya adalah sebagian tanaman Jati hangus terbakar, Asap yang pekat timbul dari kebakaran, polusi udara, sesak nafas, dan yang paling parah adalah ditemukannya daerah terdampak yang ditandai dengan warna hitam pekat yang terpantu oleh google map API.

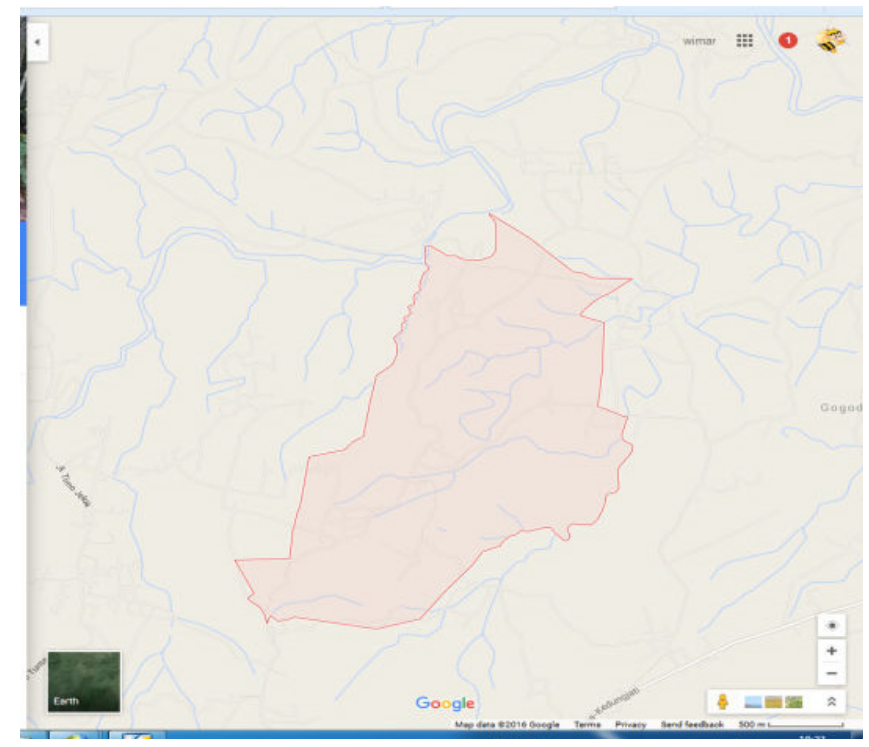

Gambar 1. Peta Desa Kalijambe

Gambar 1 merupakan peta wilayah desa Kalijambe yang memiliki batas sebelah Utara adalah Kecamatan Pringapus, sebelah Timur adalah 
Desa Rembes Kecamatan Bringin sebelah Barat adalah Desa Ngajaran Kecamatan Tuntang sebelah Selatan adalah Desa Bringin Kecamatan Bringin.

\section{Permasalahan}

Fokus masalah ini dapat diuraikan sebagai berikut; (a) Bagaimana sistem informasi geografis deteksi lokasi kebakaran lahan jati di Desa Kalijambe Kecamatan Bringin Kabupaten Semarang ? (b) Bagaimana komponen database yang akan digunakan untuk menentukkan daerah kebakaran lahan Jati di Desa Kalijambe Kecamatan Bringin Kabupaten Semarang (c) Bagaimana aplikasi sistem informasi geografis untuk melihat lokasi kebakaran lahan jati di Desa Kalijambe Kecamatan Bringin Kabupaten Semarang?

\section{Sistem Informasi Geografis}

Sebagaimana diketahui bersama bahwa dalam era globalisasi ini kemajuan teknologi sangat pesat sekali. Banyak sekali penelitian yang dilakukan untuk mendorong timbulnya penemuan baru dalam dunia teknologi,terutama teknologi Informasi. Adapun salah satu penemuan tersebut adalah sistem informasi geografis atau geographic information system (GIS). Dengan adanya teknologi ini maka akan memudahkan manusia dalam hal pemetaan lahan, dan penentuan lahan pertanian yang cocok untuk jenis tanaman tertentu sehingga dapat berproduksi secara maksimal. Perkembangan sistem informasi tak ada artinya tanpa didukung oleh kemajuan teknologi jaringan komputer. Melalui jaringan komputer maka memungkinkan dilakukannya komunikasi dan interaksi antar data yang secara fisik terpisah. Teknologi ini mengatasi semua hambatan baik dimensi waktu (dapat dilakukan kapan saja) maupun dimensi geografis atau dari tempat di mana saja yang terhubung dengan jaringan komputer.

Data yang merepresentasikan dunia nyata (real world) dapat disimpan, dimanipulasi, dan dipresentasikan dalam bentuk yang lebih 
sederhana dengan layer-layer tematik yang direalisasikan dengan lokasilokasi geografi di permukaan bumi. Hasilnya dapat digunakan untuk pemecahan berbagai masalah perencanaan dan pengambilan keputusan berkaitan dengan data kebumian.

Sistem informasi geografis (SIG) atau dalam bahasa Inggris Geographic Information System adalah sistem informasi khusus dengan menggunakan data untuk mempresentasikan dunia nyata yang dapat disimpan, dimanipulasikan dan disajikan dalam bentuk yang lebih sederhana. Fungsi dari SIG tersebut hasilnya dapat digunakan untuk pemecahan berbagai masalah perencanaan dan pengambilan keputusan berkaitan dengan data kebumian. Informasi spasial memakai lokasi, dalam suatu sistem koordinat tertentu, sebagai dasar referensinya. Karenanya SIG mempunyai kemampuan untuk menghubungkan berbagai data pada suatu titik tertentu di bumi, menggabungkannya, menganalisis dan akhirnya memetakan hasilnya. Aplikasi SIG menjawab beberapa pertanyaan seperti: lokasi, kondisi, trend, pola, dan pemodelan. Kemampuan inilah yang membedakan SIG dari sistem informasi lainnya. (Yustina dalam Wahyu, 2014:12)

"Suatu komponen yang terdiri dari perangkat keras, perangkat lunak, data geografis dan sumberdaya manusia yang bekerja bersama secara efektif untuk menangkap, menyimpan, memperbaiki, memperbaharui, mengelola, memanipulasi, mengintegrasikan, menganalisis, dan menampilkan data dalam suatu informasi berbasis geografis."

Dilihat dari definisinya, SIG adalah suatu sistem yang terdiri dari berbagai komponen yang tidak dapat berdiri sendiri-sendiri. Memiliki perangkat keras komputer beserta dengan perangkat lunaknya belum berarti bahwa sudah memiliki SIG apabila data geografis dan sumberdaya manusia yang mengoperasikannya belum ada. Sebagaimana sistem komputer pada umumnya, SIG hanyalah sebuah 'alat' yang mempunyai kemampuan khusus. Kemampuan sumberdaya manusia untuk memformulasikan persoalan dan menganalisis hasil akhir sangat 
berperan dalam keberhasilan sistem SIG.

\section{Manfaat aplikasi SIG}

GIS adalah sebuah aplikasi dinamis, dan akan terus berkembang. Peta yang dibuat pada aplikasi ini tidak hanya akan berhenti dan terbatas untuk keperluan saat dibuatnya saja. Dengan mudahnya kita bisa melakukan peremajaan terhadap informasi yang terkait pada peta tersebut, dan secara otomatis peta tersebut akan segera menunjukkan akan adanya perubahan informasi tadi. Semuanya itu dapat Anda kerjakan dalam waktu singkat, tanpa perlu belajar secara khusus

GIS berbeda dengan sistem informasi pada umumnya dan membuatnya berharga bagi perusahaan milik masyarakat atau perseorangan untuk memberikan penjelasan tentang suatu peristiwa, membuat peramalan kejadian, dan perencanaan strategis lainnya.

GIS adalah sebuah teknologi yang mampu merubah besar-besaran tentang bagaimana sebuah aktivitas bisnis diselenggarakan. Teknologi GIS memungkinkan Anda untuk melihat informasi bisnis kita secara keseluruhan dengan cara pandang baru, melalui basis pemetaan, dan menemukan hubungan yang selama ini sama sekali tidak terungkap. GIS memungkinkan kita untuk membuat tampilan peta serta menggunakannya untuk keperluan presentasi dengan menunjuk dan meng-klik-nya. GIS memungkinkan kita untuk menggambarkan dan menganalisa informasi dengan cara pandang baru, mengungkap semua keterkaitan yang selama ini tersembunyi, pola, dan kecenderungannya.

Para pelaku bisnis yang bergerak di bidang pemasaran, periklanan, real estate, dan ritel saat ini sudah menggunakan GIS untuk melakukan analisa pasar, mengoptimalkan kampanye periklanan melalui media masa, analisis terhadap bidang-bidang tanah, dan membuat model atas pola pengeluaran. GIS akan merubah banyak hal yang berkait erat dengan pekerjaan Anda, apa pun bisnis Anda tersebut. 
Keuntungan utama alat dari SIG adalah memberi kemungkinan untuk mengindentifikasi hubungan spasial diantara feature data geografis dalam bentuk peta. SIG tidak hanya sekedar menyimpan peta menurut pengertian konvensional yang ada dan SIG tidak pula sekedar menyimpan citra atau pandangan dari area geografi tertentu. Akan tetapi, SIG dapat menyimpan data menurut kebutuhan yang diinginkan dan menggambarkan kembali sesuai dengan tujuan tertentu. SIG menghubungkan data spasial dengan informasi geografi tentang feature tertentu pada peta. Informasi ini disimpan sebagai atribut atau karakteristik dari feature yang disajikan secara grafik. Sebagai contoh, jaringan jalan dapat disajikan dengan jalur tengah jalan (road centerlines), pada keadaan ini, representasi visual yang sebenarnya dari jalan tidak akan memberikan terlalu banyak informasi tentang jalan tersebut. Untuk memperoleh informasi tentang jalan, misalnya lebar atau jenis jalan, kita dapat menanyakan ke database, kemudian menentukanan simbol tampilan jalan menurut jenis informasi yang perlu ditampilkan. SIG dapat juga menggunakan atribut yang tersimpan untuk menghitung informasi baru mengenai feature peta, sebagai contoh, untuk menghitung panjang jalan tertentu atau mendeterminasi luas total dari jenis tanah tertentu. Saat ini SIG digunakan untuk aplikasi yang beragam, antara lain untuk kepentingan bisnis, universitas dan pemerintahan.

\section{Data Spasial}

Data Spasial merupakan salah satu komponen dari GIS yang berisikan tentang informasi lokasi yang memiliki koordinat-koordinat tertentu sebagai dasar referensinya. Informasi lokasi dan informasi atribut yang dapat dijelaskan pada data spasial adalah sebagai berikut: (a) informasi lokasi atau informasi spasial, berkaitan dengan titik koordinat lintang dan bujur termasuk diantaranya informasi datum dan proyeksi. (b) informasi deskriptif (atribut) atau informasi non spasial. Suatu 
lokalitas bisa mempunyai beberapa atribut atau properti yang berkaitan dengannya; contohnya jenis vegetasi, populasi, pendapatan pertahun, dan sebagainya.

\section{Format Data Spasial}

Data Spasial dapat disajikan dua format, yaitu: Pertama, vektor. Format data vektor ini mempresentasikan tentang garis, polygon, node, dan titik-titik yang menghubungkan wilayah satu dengan wilayah yang lain. Keuntungan yang didapat dari format vektor ini adalah ketepatan dalam merepresentasikan fitur titik, batasan dan garis lurus. Hal ini sangat berguna untuk analisis yang membutuhkan ketepatan posisi, misalnya pada basis data batas-batas kadaster.

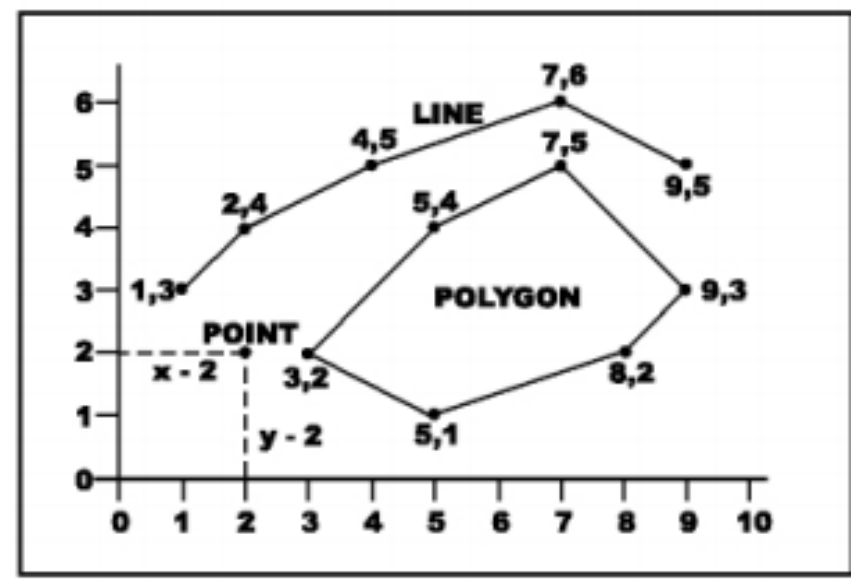

Data vektor

Gambar 2. Data Vektor

a. Raster

Data raster (atau disebut juga dengan sel grid) adalah data yang dihasilkan dari sistem penginderaan jauh. Pada data raster, obyek geografis direpresentasikan sebagai struktur sel grid yang disebut dengan pixel (picture element). Pada data raster, resolusi (definisi visual) 
tergantung pada ukuran pixel-nya. Dengan kata lain, resolusi pixel menggambarkan ukuran sebenarnya di permukaan bumi yang diwakili oleh setiap pixel pada citra. Semakin kecil ukuran permukaan bumi yang direpresentasikan oleh satu sel, semakin tinggi resolusinya. Data raster sangat baik untuk merepresentasikan batas-batas yang berubah secara gradual, seperti jenis tanah, kelembaban tanah, vegetasi, suhu tanah, dan sebagainya. Keterbatasan utama dari data raster adalah besarnya ukuran file semakin tinggi resolusi grid-nya semakin besar pula ukuran filenya.

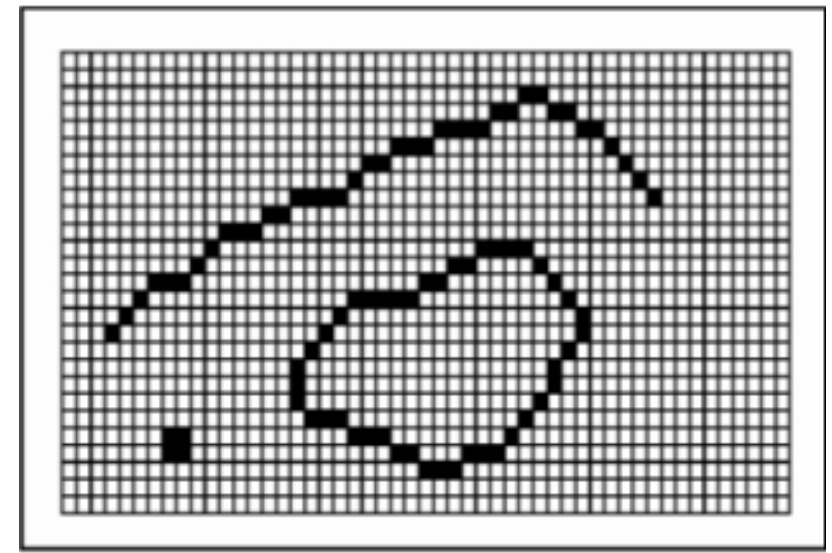

Data raster

Gambar 3. Data Raster

\section{Sumber Data Spasial}

Dalam mempelajari dan menggunakan SIG, membutuhkan beberapa sumber data, yaitu; (a) Peta Analog; antara lain peta topografi, peta tanah dan sebagainya yaitu peta dalam bentuk cetak. Pada umumnya peta analog dibuat dengan teknik kartografi, kemungkinan besar memiliki referensi spasial seperti koordinat, skala, arah mata angin dan sebagainya. Dalam tahapan SIG sebagai keperluan sumber data, peta analog dikonversi menjadi peta digital dengan cara format raster diubah menjadi format 
vektor melalui proses dijitasi sehingga dapat menunjukan koordinat sebenarnya di permukaan bumi; (b) Data dari Sistem Penginderaan Jauh antara lain citra satelit, foto udara dan sebagainya, merupakan sumber data yang terpenting bagi SIG karena ketersediaanya secara berkala dan mencakup area tertentu. Selanjutnya adanya bermacam-macam satelit di ruang angkasa dengan spesifikasinya masing-masing, kita bisa memperoleh berbagai jenis citra satelit untuk beragam tujuan pemakaian. Data ini biasanya direpresentasikan dalam format raster; (c) Data hasil pengukuran lapangan: Data pengukuran lapangan yang dihasilkan berdasarkan teknik perhitungan tersendiri, pada umumnya data ini merupakan sumber data atribut contohnya batas administrasi, batas kepemilikan lahan, batas persil, batas hak pengusahaan hutan dan lainlain; (d) Data GPS: Teknologi GPS memberikan terobosan penting dalam menyediakan data bagi SIG. Keakuratan pengukuran GPS semakin tinggi dengan berkembangnya teknologi. Data ini biasanya direpresentasikan dalam format vektor.

\section{Proyeksi}

Proyeksi secara umum adalah proses transformasi dari ruang tiga dimensi ke dalam peta yang dua dimensi. Proyeksi peta melibatkan perhitungan matematika yang mengkonversikan data dari lokasi geografisnya yang berbentuk bola atau berbentuk bola elips ke dalam lokasi representasinya pada permukaan yang rata (peta).

Penggunaan proses proyeksi ini tidak dapat menghindarkan munculnya distorsi, paling sedikit pada satu hal dari hal-hal seperti: bentuk, luas, jarak, arah dan banyak yang lainnya. Karena pengambilan keputusan tentunya harus dihasilkan dari peta-peta yang oleh karena proyeksinya telah memiliki distorsi, maka seorang pengguna peta untuk tujuan analitis harus tahu distorsi pada hal-hal apa yang ditimbulkan oleh masing-masing proyeksi dan sampai sejauh mana. 


\section{Datum}

Datum merupakan sebuah kumpulan parameter yang mendefinisikan sistem koordinat, dan sekumpulan titik kontrol yang relasi geometrisnya diketahui, baik dengan cara pengukuran maupun dengan cara penghitungan (kalkulasi). Semua datum didasarkan kepada bentuk bumi yang bola elips.

Datum seringkali dipergunakan untuk merepresentasikan bentuk bumi pada lokasi tertentu dengan lebih baik. Karenanya akurasi datum lokal sangat dibatasi pada area sekitar titik asalnya semata. Sehingga pencarian lokasi dan penampakan permukaan bumi semakin detail.

Datum yang dipergunakan pada peta-peta terbitan Bakosurtanal yang baru adalah DGN (Datum Geodesi Nasional) yang menggunakn parameter yang sama dengan Datum WGS 84, sementara peta peta sebelumnya banyak yang masih menggunakan Datum Indonesia 74 Datum-datum lain dari daftar di atas banyak dipergunakan oleh petapeta terbitan lama yang di cetak oleh misalnya US Army Map Service, Join Operation Ground Graphic Survey (JOG).

\section{Google MAP API}

Application programming interface (API) adalah fungsi fungsi pemrograman yang disediakan oleh aplikasi atau layanan agar layananan tersebut bisa diintegrasikan dengan aplikasi yang dibuat. Sehinnga Google MAP API dapat diartikan sebagai fungsi fungsi pemrograman yang disediakan oleh Google maps agar Google maps bisa diintegrasikan kedalam Web atau aplikasi yang sedang buat.

\section{Metode Penelitian}

Dalam penelitian ini yang menjadi obyek adalah mendeteksi kebakaran lahan jati di Desa Kalijambe, Kecamatan Bringin, Kabupaten 
Semarang. Fokus utama dalam penelitian ini adalah menemukan dan memantau lahan-lahan tanaman jati setelah terjadi kebakaran sehingga dapat segera dipadamkan sebelum meluas. Karena disekitaran lahan jati tersebut banyak tanaman pertanian dan rumah penduduk yang sebagian besar mudah terbakar dan juga didukung adanya angin yang berhembus lumayan besar.

Dalam pengambilan sampel dilakukan secara acak di desa-desa yang masuk ke administrasi Kecamatan Bringin, karena Kecamatan Bringin masih banyak lahan yang luas dan ditanami tanaman Jati dan Karet. Desa Kalijambe adalah salah satu yang diambil sampel untuk mewakili desa yang lain di Kecamatan Bringin. Studi literatur dan studi lapangan juga dilakukan dalam penelitian ini untuk menambah data.

Variabel yang akan diukur hanya menggunakan titik koordinat (x dan y) untuk daerah terdampak kebakaran menggunakan google map API. Dengan menggunakan titik koordinat untuk mengetahui daerah-daerah sekitar yang terkena dampak dari kebakaran lahan.

Perlengkapan yang digunakan pada penelitian ini antara lain berupa: (a) Hardware: jenis komputer Netbook model Samsung NC 208/ NC 108, processor Intel (R) Atom (TM) CPU N570@1.66Hz (4CPUs) 1.7GHz, Bios: Phonix SecureCore(TM) NB Version 01VV.M013.20110704. RHU, Memori 2048MB RAM. (b) Software: Operating System: Windows 7 Ultimate 32 bit (6.1 build 7600), Aplikasi Google MAP API versi 3.0. Database: MySQL versi 2.11.7.

Penelitian ini langkah pertama adalah mencari titik koordinat terlebih dahulu untuk pemetaan daerah yang terdampak kebakaran. Setelah mengetahui titik koordinatnya, selanjutnya kita buat rasternya, sehingga terbentuk suatu wilayah yang terdampak kebakaran dengan tanda warna hitam: 
Tabel 1. Titik Koordinat Titik Rawan Kebakaran

\begin{tabular}{cc}
\hline Titik X & Titik Y \\
\hline-7.207120 & 110.5302 \\
-7.207013 & 110.5298 \\
-7.207162 & 110.5296 \\
-7.207511 & 110.5294 \\
-7.207774 & 110.5294 \\
-7.208224 & 110.5295 \\
-7.208596 & 110.5295 \\
-7.208384 & 110.5292 \\
-7.208700 & 110.5295 \\
-7.209062 & 110.5293 \\
-7.209078 & 110.5296 \\
-7.209344 & 110.5298 \\
-7.209895 & 110.5299 \\
-7.209759 & 110.5304 \\
-7.209533 & 110.5307 \\
-7.209408 & 110.5311 \\
-7.209206 & 110.5312 \\
-7.208458 & 110.5313 \\
-7.207612 & 110.5314 \\
-7.207362 & 110.5307 \\
-7.207191 & 110.5302 \\
-7.206989 & 110.5298 \\
\hline
\end{tabular}

\section{Hasil Penelitian}

Penelitian ini menghasilkan suatu aplikasi sistem informasi geografi (SIG) untuk deteksi kebakaran lahan Jati di Desa Kalijambe, Kecamatan Bringin, Kabupaten Semarang. Aplikasi ini dapat digunakan kapan saja untuk memantau dan mendeteksi kebakaran lahan Jati di Desa Kalijambe. 


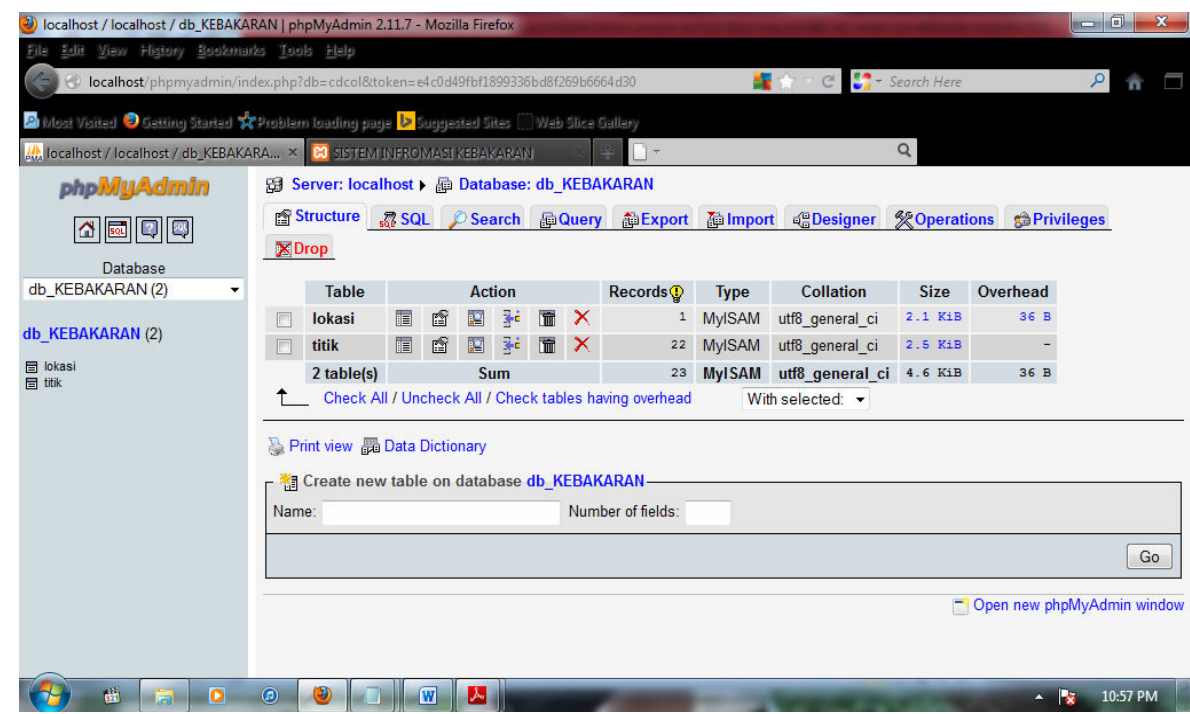

Gambar 4. Database Kebakaran Lahan Jati

ambar 4 menjelaskan tentang komponen database yang akan digunakan untuk menentukkan daerah kebakaran lahan Jati. Dalam database tersebut ada dua tabel yaitu lokasi dan titik. Isi dari tabel lokasi adalah Id_wilayah, nama lokasi dan foto. Pada tabel ini digunakan sebagai navigasi pencarian daerah. Isi database tabel lokasi dapat dilihat pada Gambar 5. Sedangkan isi dari tabel titik adalah id_titik, no, id, x, dan $\mathrm{y}$. Tabel titik digunakan untuk memasukkan titik koordinat $\mathrm{x}$ dan $\mathrm{y}$ sebagai lokasi daerah terdampak kebakaran. Isi dari database tabel titik dapat dilihat pada Gambar 6. 


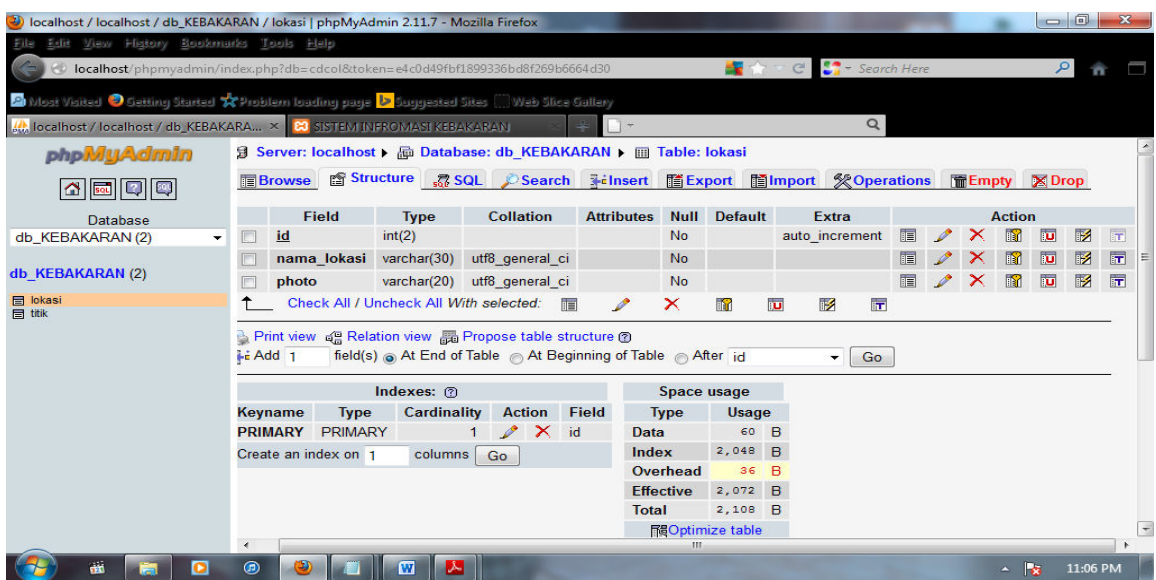

Gambar 5. Isi Database Tabel Lokasi

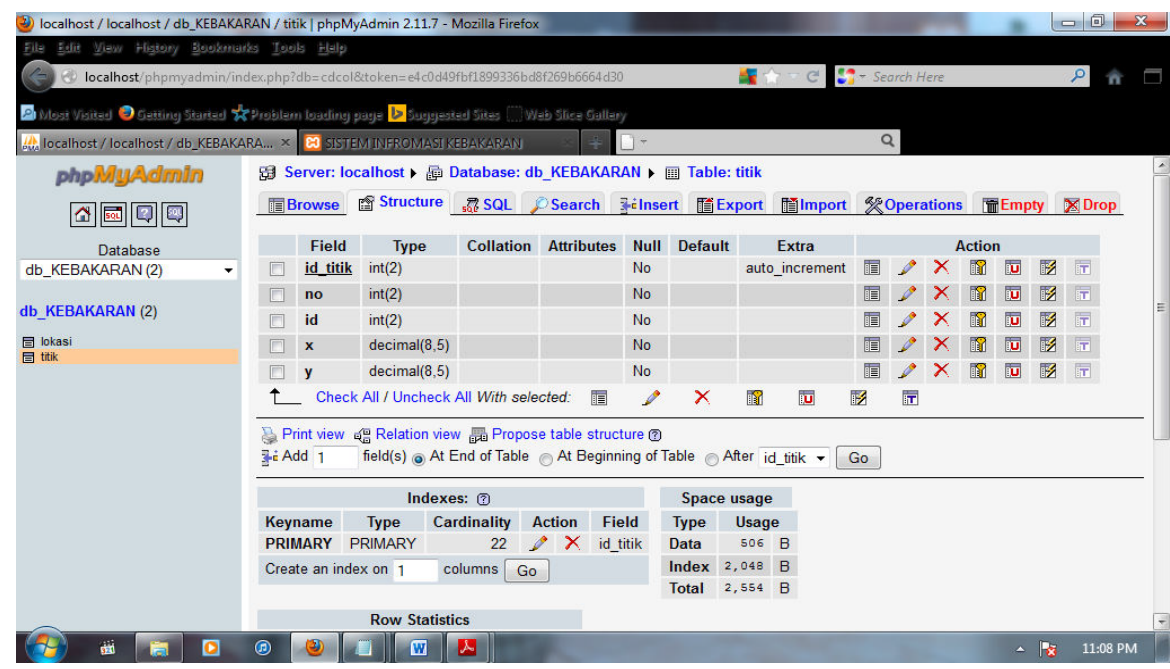

Gambar 6. Isi Database Tabel Titik

Adapun aplikasi sistem informasi geografis yang dibuat dapat dilihat pada Gambar 7. Dalam aplikasi ini terdapat menu lokasi kebakaran, Gulon, dan lihat semua lokasi. Menu lokasi kebakaran ini digunakan untuk melihat daerah yang terkena kebakaran lahan Jati secara detail. Di sini hanya ditampilkan wilayah diseputar kebakaran. Menu Gulon digunakan untuk pemetaan daerah-daerah yang terdampak kebakaran yang berada di sekitarnya. Menu lihat semua lokasi digunakan 
untuk melihat semua wilayah yang terkena dampak kebakaran lahan Jati hingga ke desa-desa di sekitarnya.

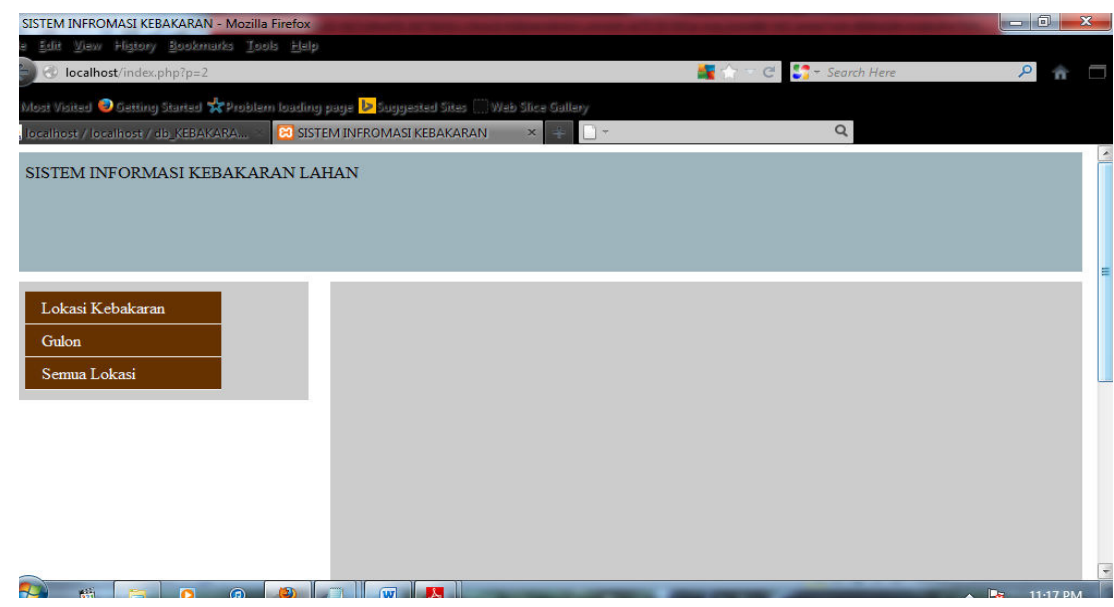

Gambar 7. Sistem Informasi Geografis Deteksi Kebakaran Lahan Jati

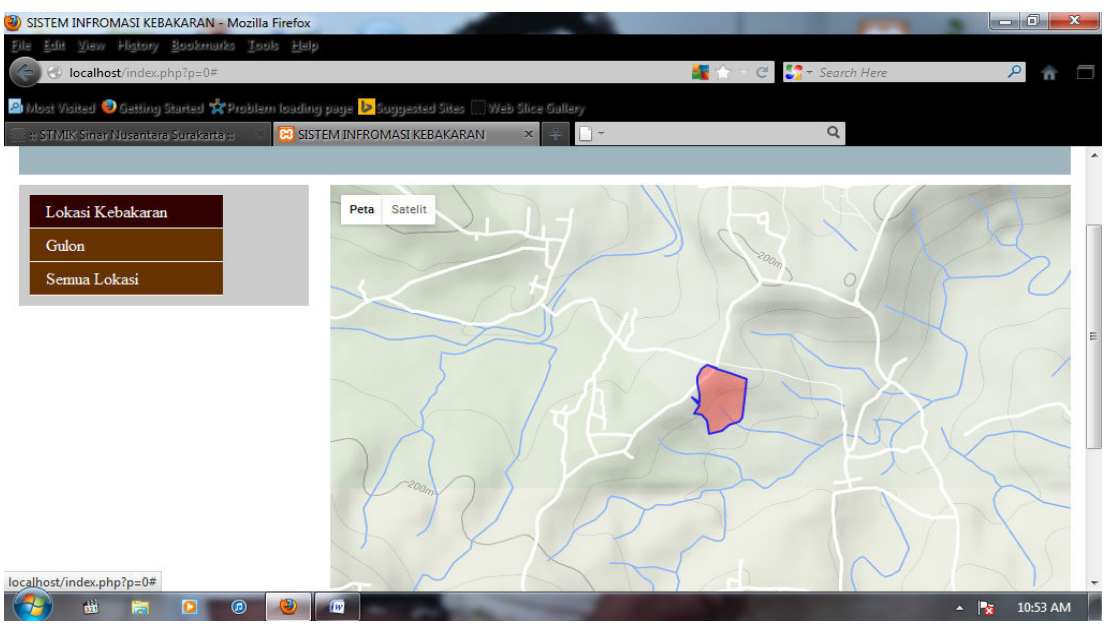

Gambar 8. Lokasi Kebakaran dengan Menggunakan Peta

Gambar 8 menjelaskan jika user mengklik tombol lokasi kebakaran akan terdapat dua versi untuk melihat obyek, yaitu melihat obyek dengan menggunakan peta dan melihat obyek dengan menggunakan satelit. Pada Gambar 8 merupakan penampakan suatu obyek daerah yang terdampak kebakaran jika dilihat menggunakan peta. 
INJECT: Interdisciplinary Journal of Communication, Vol.1, No.1, Juni 2016: h. 63-80

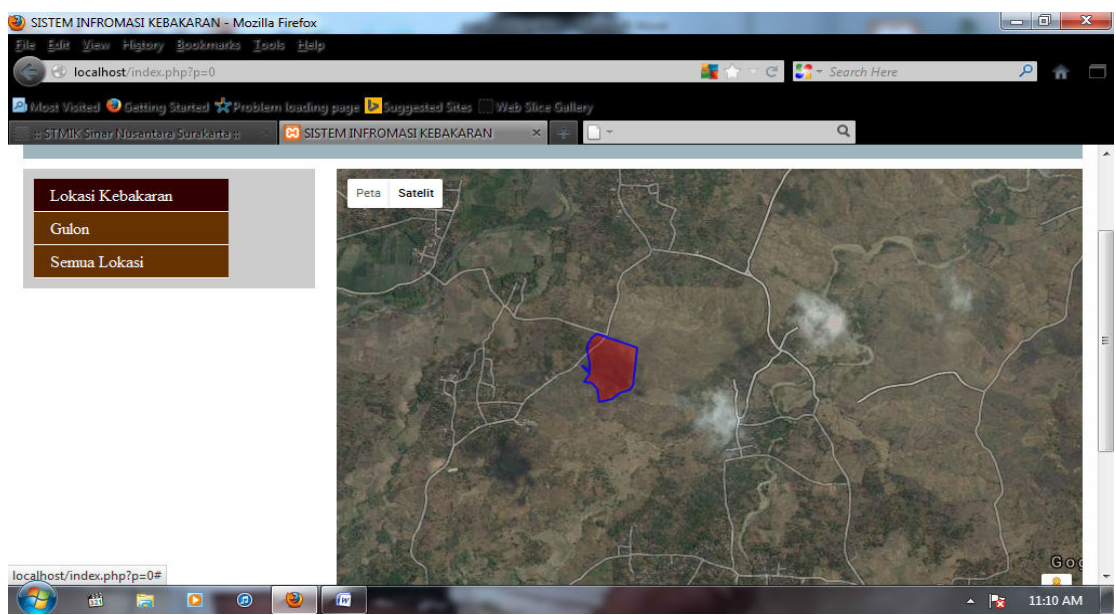

Gambar 9. Lokasi Kebakaran dengan Menggunakan Satelit

Pada Gambar 9 menjelaskan penampakkan lokasi kebakaran lahan jika menggunakan satelit. Dengan bantuan satelit, user dapat mengetahui daerah yang terdampak kebakaran lahan. Warna merah menjelaskan tentang lahan yang terbakar dan warna Biru merupakan batas-batas wilayah yang terdampak. Adapun gambar putih seperti halnya awan menandakan wilayah yang terkena asap kebakaran, dan wilayah yang berwarna hitam merupakan wilayah yang telah habis terbakar lahannya.

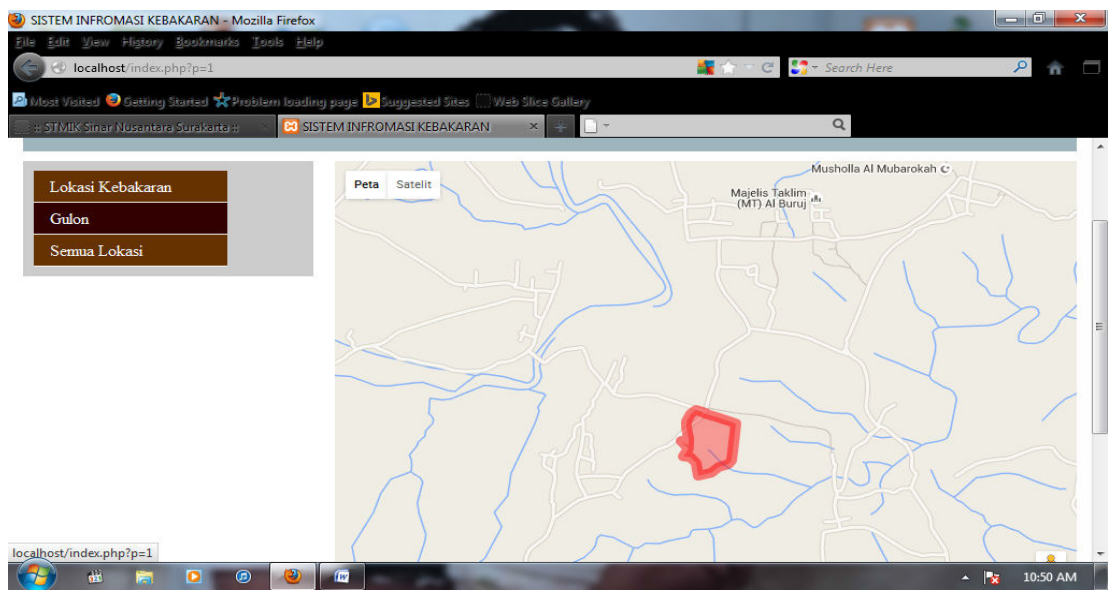

Gambar 10. Gulon 
Pada Gambar 10 menjelaskan Gulon daerah terdampak kebakaran. Pada gambar tersebut disajikan dalam bentuk raster dengan menggunakan peta. Tampak gambar yang terdampak ditandai warna merah.

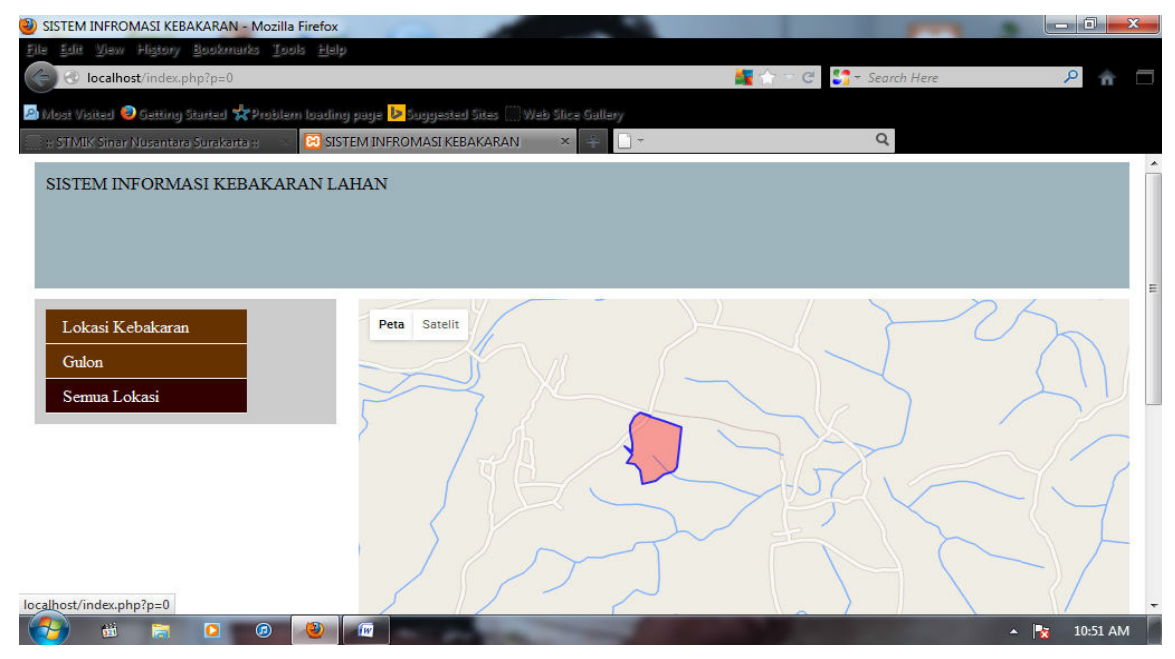

Gambar 11. Semua Lokasi

Gambar 11 menjelaskan keadaan semua lokasi yang terkena dampak kebakaran lahan. Pada gambar tersebut, user dapat melihat, memantau dan menganalisa daerah-daerah yang terkena dampak kebakaran dan daerah rawan kebakaran lahan, sehingga dapat membantu pencegahan dini.

\section{Simpulan}

Dari uraian di atas dapat disimpulkan bahwa beberapa upaya yang dapat dilakukan untuk tindakan pencegahan kebakaran lahan Jati di Desa Kalijambe, Kecamatan Bringin, Kabupaten Semarang. Salah satunya adalah melakukan sosialisasi akan dampak dari kebakaran lahan ke warga. Walaupun aplikasi sistem informasi Geografis deteksi kebakaran lahan Jati ini dapat dijadikan sebagai alat untuk mendeteksi kebakaran, namun peran warga sangatlah penting untuk pencegahan kebakaran. Untuk penelitian kedepan adalah perlunya penambahan fitur-fitur yang 
lebih lengkap semisal penambahan fitur dapat mengetahui rute terdekat untuk evakuasi warga dan jalur untuk mobil pemadam kebakaran apabila kebakaran lahan sudah sangatlah parah.

\section{Daftar Pustaka}

Utami Wahyu, R.Y. 2014. Sistem Informasi Geografi. Surakarta: STMIK Sinar Nusantara.

Indrasmoro, P.G. 2013. "Geographic Information System (GIS) Untuk Deteksi Daerah Rawan Longsor Studi Kasus di Kelurahan Karang Anyar Gunung Semarang". Jurnal GIS. Semarang.

Putra Adi, C. p. 3, viewed 10 Maret 2016, http://www.candra.web.id/ home/.

Shodiq, Amri. p. 1, viewed 17 Maret 2016, http://amrishodiq.blogspot. com.

Warino, Joko. p. 1, viewed 08 Maret 2016, http://jokowarino.id/. Hendra. p. 4, viewed 08 Maret 2016, http://www.linkdesain.com/. 